\title{
Egy hazai vállalat szervezeti magatartásának vizsgálata, különös tekintettel a motivációra
}

\author{
A. NÉMETI ${ }^{1}$, A. MATKÓ2 \\ ${ }^{1}$ Debreceni Egyetem, Műszaki Kar, Műszaki Menedzsment és Vállalkozási Tanszék andi.nemeti92@gmail.com \\ ²Debreceni Egyetem, Műszaki Kar, Műszaki Menedzsment és Vállalkozási Tanszék andim@eng.unideb.hu
}

Absztrakt. A XXI. században a globális versenyképesség jelenti a vállalkozások számára az egyik legnagyobb kihívást. A vállalkozásnak magas színvonalú és kiegyensúlyozott müködést kell megvalósitania ahhoz, hogy meg tudjon felelni a globális kihívásnak. A cégeknek erre a jelenlegi helyzetre kell minél hamarabb jól múködô stratégiát kialakítani, mielött az összes tehetséges szakmunkás külföldre vándorolna a jobb remények érdekében, még nagyobb munkaeröhiányt okozva ezzel a piacon. Tanulmányunk célja az volt, hogy a vállalaton belül megvizsgáljuk a szervezeti magatartást, illetve a motivátorokat, és javaslatot tegyünk a fejlódési lehetôségekkel kapcsolatban. A szervezet elemzéséhez először a szervezetben dolgozókat soroltuk be a generációs elméleteket alapul véve. A baby boom generáció számára motiváló tényezóként jelenik meg a magas munkabér, a növekvő béren kívüli juttatások, a jó munkatársi kapcsolatok, illetve az önálló munkavégzés. Az X generációnak is a magas munkabér és a jó munkahelyi kapcsolatok a legfőbb motiváló tényezők, illetve a modern technikai berendezések. Az Y generációt leginkább a jó munkahelyi kapcsolatok, a magas munkabér, valamint a béren kívüli juttatások növelése ösztönzi. A cégnél dolgozó legfiatalabb generáció szinte hallani sem akar a felelősségi kör bővitésérôl és az előléptetési lehetôségről. Számukra is meghatározó a biztos munkahely.

Abstract. The XXI. In the 20th century, global competitiveness is one of the biggest challenges for businesses. The business needs to implement high quality and balanced operations to meet the global challenge. Firms need to develop a well-functioning strategy as soon as possible before all talented skilled workers migrate abroad for better hopes, causing even greater labor shortages in the market. The purpose of our study was to examine organizational behavior and motivators within the company and to propose development opportunities. For the organization to be analyzed, we first classified employees in the organization based on the generation theory. The high-wage, increasing fringe benefits, good employee relations, and self-employment are the motive for the baby boom generation. The $X$ generation also has high wages and good working relationships with the main motivating factors and modern technical equipment. Generation $Y$ is best promoted by good workplace relationships, high wages and increased fringe benefits. The youngest generation in the company does not even want to hear about extending responsibility and promoting it. For them, the sure job is also decisive.

\section{Bevezetés}

A XXI. században a globális versenyképesség jelenti a vállalkozások számára az egyik legnagyobb kihívást. A vállalkozásnak magas színvonalú és kiegyensúlyozott működést kell megvalósítania ahhoz, hogy meg tudjon felelni a globális kihívásnak. A termékek és szolgáltatások piacán lévő versenyképességnek a kihívása mellett manapság hazánkban a vállalkozások nagy részének problémát 
jelent az alkalmazottainak a megtartása. Ezzel egyidőben a munkáltatók egyre nagyobb mértékben várják el a különböző szakmai- és tudományterületek tudásanyagát kombinálni, szintetizálni tudó, azonnal alkalmazható tudással rendelkező pályakezdő végzetteket, sokszor mindhiába (ÁrvánéKatonáné-Gál, 2017). A cégeknek erre a jelenlegi helyzetre kell minél hamarabb jól működő stratégiát kialakítani, mielőtt az összes tehetséges szakmunkás külföldre vándorolna a jobb remények érdekében, még nagyobb munkaerőhiányt okozva ezzel a piacon. A vizsgált vállalat estében is jelen van ez a probléma, ugyanis a cég vezetőségének egyre sűrübben kell szembenéznie azzal a helyzettel, hogy egy-egy jó szakember inkább külföldre kívánkozik, hogy szerencsét próbáljon. A kilépett dolgozó helyére sok esetben csak nagyon nehezen, több jelentkező kipróbálása után, vagy egyáltalán nem sikerül ugyanolyan kiváló munkavállalót találni. Tanulmányunk célja, hogy ezt a helyzetet a vállalaton belül megvizsgáljuk és javaslatot tegyünk a fejlődési lehetőségekkel kapcsolatban.

\section{Motivációs elméletek}

Az egyének megfigyelhető magatartására a motiváció szolgál magyarázattal. A viselkedésekre a motívumok - azon dolgok, amik cselekvésre késztetnek - hatással vannak, többnyire közvetlenül nem láthatóak, sőt számos esetben az is előfordulhat, hogy a végrehajtott cselekvésében még az adott személy sincs tudatában. A motívumokat három fóbb csoportra bonthatjuk. Az elsődleges motívumok, amik fiziológiai alapúak és ösztönösek. Az általános motívumok pszichés jellegúek, amelyek még szintén nem tanultak, és az utolsó csoport a másodlagos motívumok, melyeket már tanulás útján lehet elsajátítani (Tóthné, 2004).

A motivációs elméletekről szó szoros értelemben csak a XVII. századot követően lehet beszélni. Ösztönelmélet a veleszületett ösztönökre, az emberi viselkedés nem tudatos motivátoraira koncentrált. Descartes szerint az emberek a legésszerübben és legegyszerübben választanak a lehetőségek közül a tudásuknak megfelelően. Behaviorizmus szerint a tanulás, a tapasztalat képes befolyásolni a magatartást, valamint hogy az emberi viselkedés egyáltalán nem rugalmatlan (Atkinson, 1964). A Drive-megközelítések szerint John A. McDougall Úgy gondolta, hogy a legfontosabb meghatározó tényezője az emberi viselkedésnek a tíz fő emberi ösztön, bár nyomatékosította, hogy ezek közül hét érzelmi állapoton keresztül fejti ki a hatását (Klein - Klein, 2012). Az ösztöneikre támaszkodva döntik el, hogy milyen módon viselkedjenek. Így a tanulás nem tudja módosítani az ösztönt magát, csak az arra adott magatartási választ. A drive, a hajtóerő nem más, mint egy olyan belső erő, amely a magatartást motiválja. A kognitív-megközelítések szerint a saját magának megfogalmazott elvárások Kurt Lewin véleménye szerint igen fontos szerepet játszanak egy személy teljesítményképességében. (K. Kópházi, 2007). A tartalomelméletek azok a motivációs elméletek, melyek a szervezetekben észlelhető magatartást a viselkedéseket kiváltó okokra koncentrálva értelmezik. Maslow elméletének alapvető filozófiája szerint az egymástól független szükségletek hierarchikus sorrendben befolyásolják az emberi viselkedést. Ez alapján elmondható, hogy amíg a tudatunkat az alacsonyabb rendű szükségletek kielégítése foglalkoztatja, addig a magasabb rendű szükségletek a háttérbe szorulnak. Herzberg miszerint azok a faktorok, amelyek véget vetnek az elégedetlenségnek, egyidejüleg elégedetté is teszik az egyént, nem felel meg a valóságnak. „Eredményeiből az derül ki, hogy a munkahelyi elégedettséget főként a motivátor tényezők megléte 
váltja ki, míg az elégedetlenség megszüntetése a higiénés szükségletek kielégítése révén érhető el." (Takács et al., 2012:2). „A higiénés tényezők meglétének hiánya torzíthatja, illetve semlegesítheti a motivációs eszközök hatását, ami például nagyban befolyásolhatja a szervezeti elkötelezettséget." (Takács et al., 2012:4). A motivátorok a munkahelyi elégedettséget kiváltó fő tényezők. A munka belső lényegéhez füződnek, valamint a munka tartalmára, a teljesítési és a fejlődési igényekre ható speciális egyéni tulajdonságokkal állnak kapcsolatban. Ezek alapján motivátoroknak tekinthetőek az alábbiak: elismertség, fejlődés, elért teljesítmény, nagyobb felelősség, kiterjedtebb hatáskör, önállóság a munkavégzésben, illetve maga a munka. Árváné et al., (2016) szerint mind az elvárások, mind a motivációk kutatása fontos és előremutató feladat, nemcsak a munkaerőpiac szereplői körében, hanem már az oktatási rendszerek keretein belül is.

\section{Motiváció 3.0}

Motiváció 1.0 Maslow-féle szükséglet hierarchiáján alapszik. Ez alapján az egyént elsősorban a biológiai belső tényezők ösztönzik, és csak másodsorban reagálnak a külső környezeti faktorokra. A következő elmélete a Motiváció 2.0, amely az előző verziót a külső jutalmazás és büntetés fogalmával bővíti ki. Ez rendkívül bevált rendszer volt a gazdasági fejlődések és az ipari forradalom idején. „Ha a megfelelő munkát a megfelelő időben és megfelelő módon végzik, a gépezet hibátlanul működik. És, hogy ez valóban így is legyen, egyszerűen csak jutalmazni kell az elvárt magatartást, és büntetni azt, amit rosszallunk." (Pink, 2010:32). A Motiváció 2.1 elméletét McGregor állítása inspirálta, amely szerint az emberek eredendően nem lusták és a motiváció egy magasabb igénye létezik az egyénben. A dolgozók nagyobb önállóságot és rugalmasabb munkaidőt kaptak, valamint enyhített öltözködési szabályokat alakítottak ki. A „ha-akkor” típusú ösztönzést preferálták. Ez azt jelenti, hogy a dolgozó akkor kapja meg, amit ígértek neki, ha elvégzi a kiadott feladatot. Vagyis a külső jutalmazás volt a fő motiváló eszköz. Viszont ma már a gyakorlatban ez nem felel meg a valóságnak, teljes frissítésre van szükség. Így jött a Motiváció 3.0 elmélete. Pink a munka elvégzését két kategóriába osztályozza. Az egyik az algoritmikus feladatok, ami a szabályozott robotszerű munkákat jelenti. Tehát a beosztottak utasításokra meghatározott feladatokat (nem feltétlenül fizikai munkát) hajtanak végre az elvárt eredményért. Ilyen például a szalagmunka egy konzervgyárban. A másik a heurisztikus feladatok csoportja, ami a kreatív munkáról, az önállóságról, valami új, eddig ismeretlen megoldásmenet megszületéséről szóló nem rutinszerű munka. A büntetés és a jutalmazás jól működő ösztönző eszköz az algoritmikus feladatoknál, ugyanakkor a heurisztikus munkák esetében ez romboló hatással bír hosszútávon (Pink, 2010). A feladat elvégzése belső elégedettség érzéssel járt, így beigazolódott, hogy nemcsak a külső és a biológiai jutalmazás lehet motiváló eszköz. Amerikában már vannak úgynevezett ROWE (Results-only working environment: eredményorientált munkakörnyezet) munkahelyek, amelyek jellemző vonása, hogy a munkavállalóknak nem kötelező bemenni dolgozni, hiszen akár otthonról is elvégezhetik a feladataikat ráadásul a nap bármely időpontjában. A vezetőség számára csak az a lényeg, hogy a munka el legyen végezve. 


\section{Generációk}

Egy adott szervezeti kultúrát jól körülhatárolni akkor lehetséges és viszonylag egyszerúbb, ha tagjai közel azonos generációhoz tartozva, nagyrészt hasonló uralkodó értékrenddel rendelkeznek (Gál et al., 2017). Élesen elég nehéz elkülöníteni a különböző generációkat, hiszen nyilvánvalóan átfedések vannak az egyes évek között, ráadásul a megannyi szakirodalomban sincs megfogalmazva egységes nézőpont. Az sem lényegtelen, hogy a besorolás földrajzilag hol történik, mivel egyes területeken például Európában és az USA-ban eltérő lehet. A veterán generáció - egyes szakirodalmak szerint építő, csendes generáció - tagjai ma már jellemzően nem aktív a munkaerőpiacon (Anantatmula Shrivastav, 2012). A világválság és a háború gyermekei olyan környezetben nőttek fel, amelyben az alkalmazkodás a siker záloga. Többnyire egész életükön keresztül egy munkaadónál és egy szakterületen dolgoztak. Ebben az időszakban Magyarországon az elsődleges jellemvonása az erős központi irányítás volt a munkaerőpiacon, ezért az embereknek leginkább a termelőszövetkezetek és az állami gazdaságok nyújtottak munkát. Akkoriban jellemző volt még a teljes foglalkoztatottság és a megtermelt javak igazságos elosztására törekedtek (Tari, 2010). A baby boom nemzedék a XX. század közepének szülötteit a munkahely és az egymás iránti tisztelet, a fegyelem, a kitartás, a merev konzervatív gondolkodásmód jellemzi (Tari, 2010). Schaffer Beáta szerint „a baby boom generáció tagjainak egész élete során jellemző volt a viszonylagos szűkösség szerte a világban, ezért ők ideje korán megtanulták, hogyan kell takarékosan gazdálkodni az erőforrásokkal." A kétkeresős családmodell ebben a korszakban terjedt el, amely sietette a női egyenjogúság felgyorsulását, valamint a nők a közép-és felsőfokú képzésben való tömeges megjelenését. A baby boom generáció meglehetősen felkészült, rengeteget megélt nemzedék. Azonban az eddig megszokott biztonság és nyugalom szertefoszlott. Az embereknek akkoriban kellett rádöbbenniük, hogy nincs már nyugdíjas állás, csak hajtás és kényszerhelyzetek vannak, amelyben állandóan jelen kell lenni. X generáció tagjai gyakran szülői felügyelet nélkül maradtak otthon, mivel a két-jövedelmű családmodell volt a társadalmilag elfogadott. Az otthon látott példát követve arra törekednek, hogy élvezzék a munka után eltöltött idejüket, valamint megtalálják az egyensúlyt a magánélet és a munka között. Ez a generáció már felfedezte, hogy csak akkor lehet sikeres a munkahelyén, ha menedzseli önmagát. Az X generáció tudatában van annak, hogy milyen a biztonság elvesztése, hiszen már látta a szüleinél, az első munkahelyeinél érzékelhette, hogy egyáltalán „nincs odaragasztva a székhez”. Az újonnan betelepült multinacionális vállalatok versenyképes fizetést kínáltak a munkába állásukkor, amivel együtt megkapták a korlátlan munkaidőt és a munkahelyi stresszt is. Aktív, buzgó generáció, akik a munkájuk során a csoportos feladatokat preferálják a szoros alá-fölérendeltségi viszonnyal szemben. Minél több hozzáadott értéket próbálnak termelni a szervezet számára, hogy ezzel is a fejlődést segítsék elő. Az Y generáció számára az elektronikus világ már egy alapvető dolog. Gyermekkorukban találkozhattak az internet adta lehetőségekkel, és később az egyre modernebb eszközök kezelésével ismerkedhettek meg. Rájöttek, hogy a fogyasztó társadalomban csak a siker, a karrier, a pénz visz előrébb, így számukra elsőrendû fontosságúvá váltak ezek (Tari, 2010). Az X generációval ellentétben, nemcsak hogy önbizalommal tesznek fel kérdéseket, de az évekig bevált módszereket is megkérdőjelezik, nem ragaszkodnak az addig bevált szabályrendszerekhez sem. Az Y generáció a munkahelyükre egy kreatívműhelyként tekintenek, ahol kényelmesen tudnak dolgozni, ötleteiket egymással megosztva. A 
Z generáció esetében a születések száma jelentősen visszaesett, így a korosztály legtöbb tagja egykeként nőtt fel. Ebből kifolyólag is adódhat majd az a tulajdonságuk, hogy nem lesznek csapatjátékosok. Az oktatást viszonylag hamarabb kezdik el, és jóval később fejezik be, mint az előttük lévő generációk tagjai (Ferincz - Szabó, 2012; Trunk, 2009). A figyelmük már teljesen megoszlik. Pontosan ebből adódik, hogy a pontosság helyett inkább a sebességet részesítik előnyben és az információ utáni vágyuk csillapíthatatlan. A Z generáció nyolc speciális jellemzővel rendelkezik: a szabadság, a testre szabhatóság, az együttműködés, a részletesség, az integrálás, az innováció, a sebesség és a jókedv. Az emberiség történetében valószínűleg az alfa generáció fog a legtovább élni, a legmagasabb iskolai végzettséggel rendelkezni, ugyanakkor teljesen a világháló foglyai lesznek. Nagy valószínűséggel egyedüli gyerekek lesznek és egyedül is fognak élni. Azt remélik, hogy ez a korosztály képes lesz megtalálni a válaszokat a kihívásokra, és azt, hogy velük minden újra kezdődik, új lehetőséget kapnak.

\section{A szervezeti magatartást befolyásoló tényezők}

Terepmunkánk során megfigyeléseink igazolták azt a feltevésünket, hogy a több mint 20 éve fennálló vállalat jelenlegi legnagyobb problémája az, hogy nehezen tudja megtartani az alkalmazottait. Jelenleg 147 fő dolgozik összesen a szervezet különböző területein. Az elmúlt évben igen magas fluktuáció figyelhető meg, hiszen 40 munkatárstól vált meg a cég, ugyanakkor ezt kompenzálva 45 új munkavállaló alkalmazása mellett döntött. A vállalat működését megfigyelve, illetve személyes interjúk során az alábbi tényezőket gyűjtöttük össze a fluktuációval kapcsolatban. Egy munkavállalót a munkájának feladására leginkább az emberi kapcsolatokból származó nehézségek késztetik. További nehézséget jelent a nem megfelelő probléma- és konfliktuskezelés a vezetők és a beosztottak között. A vállalat korszerű gépállománnyal rendelkezik, modern technológiát alkalmaz a gyártás során, azonban van néhány olyan általa használt program, ami fejlesztésre szorul. Emellett gyakran belső informatikai problémák is előfordulnak. A cég életét külső, környezeti tényezők is befolyásolják. Néhány beszállító a kiszervezett munkákat nem megfelelő minőségben gyártja le, vagy munkálja meg. Ráadásul számos esetben nem is az adott külső vállalkozás, hanem a belső munkaerő javítja ki a hibát.

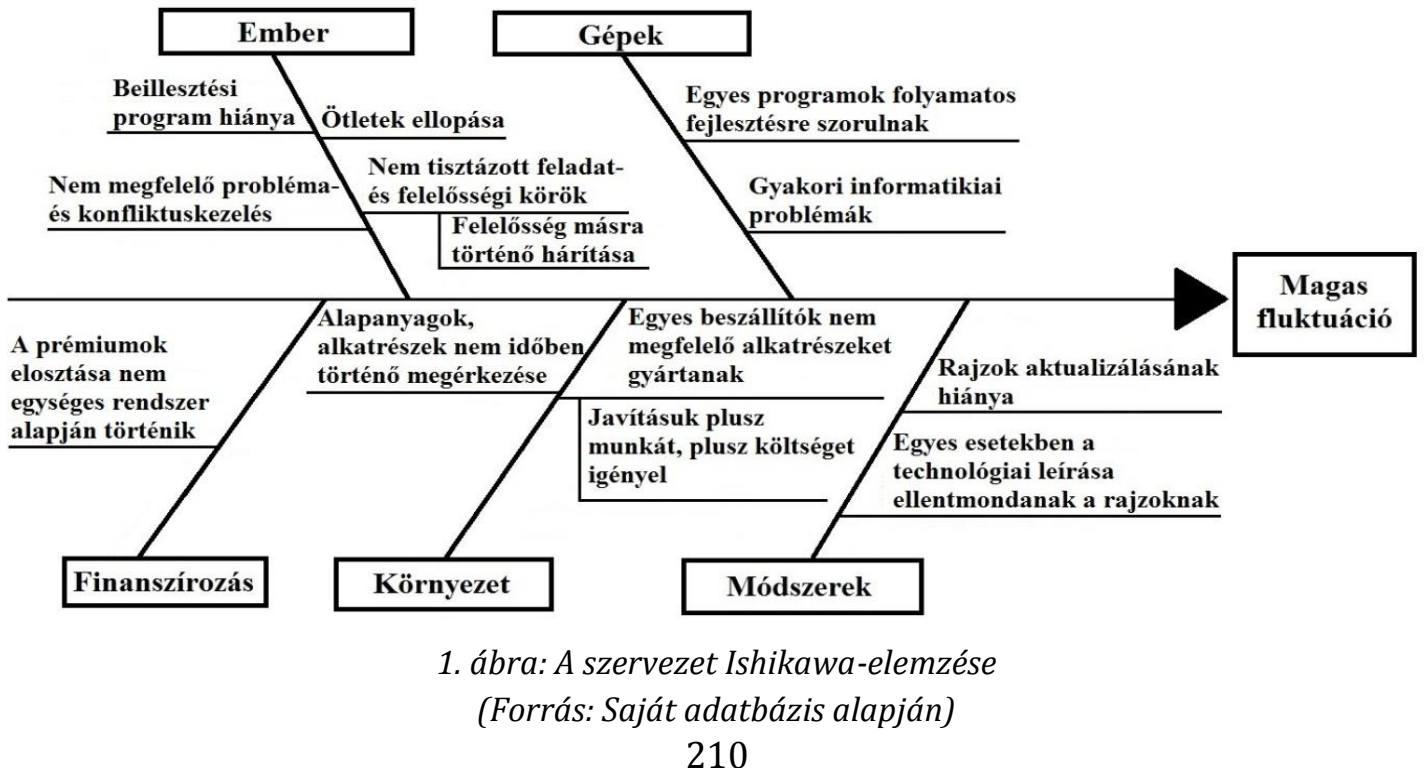

210 


\section{Kutatás}

Kvantitatív módszeren alapuló önkitöltős kérdőívet állítottunk össze. A társaság munkavállalóit a szervezeti hierarchiában elfoglalt pozíciójuk alapján osztottuk két csoportra, a vezetőkre és a beosztottakra. A kérdőív összesen 6 kérdésből állt. Az első, egy összevont mennyiségű kérdés, amelynek attribútumai az eltérő kategóriákba besorolt születési éveket adja meg a válaszadó. Az alapkérdések közül számunkra ez a leglényegesebb, mivel ennek alapján tudjuk beazonosítani, hogy a kitöltő melyik generációhoz sorolható be. Az állításokat egy Likert-skálán kellett pontozni 1-5-ig, ahol az 1 jelentése egyáltalán nem jellemző, az 5 jelentése pedig, hogy teljes mértékben jellemző. Ebben a kérdéssorban a kitöltőket a vállalat jelenlegi helyzetének értékelésére kértük. 136 beosztottjából összesen 118 fő töltötte ki, amelyből 19 érvénytelen volt. Így összesen 99 kérdőívet elemeztünk. A 2. ábra a kérdőívet kitöltők korcsoportok szerinti százalékos megoszlást szemlélteti. A kitöltők közül 12 fő (12,12\%) a baby boom generációt, 43 fő (43,43\%) az X generációt és 44 fő (44,44\%) az Y generációt erősítette.

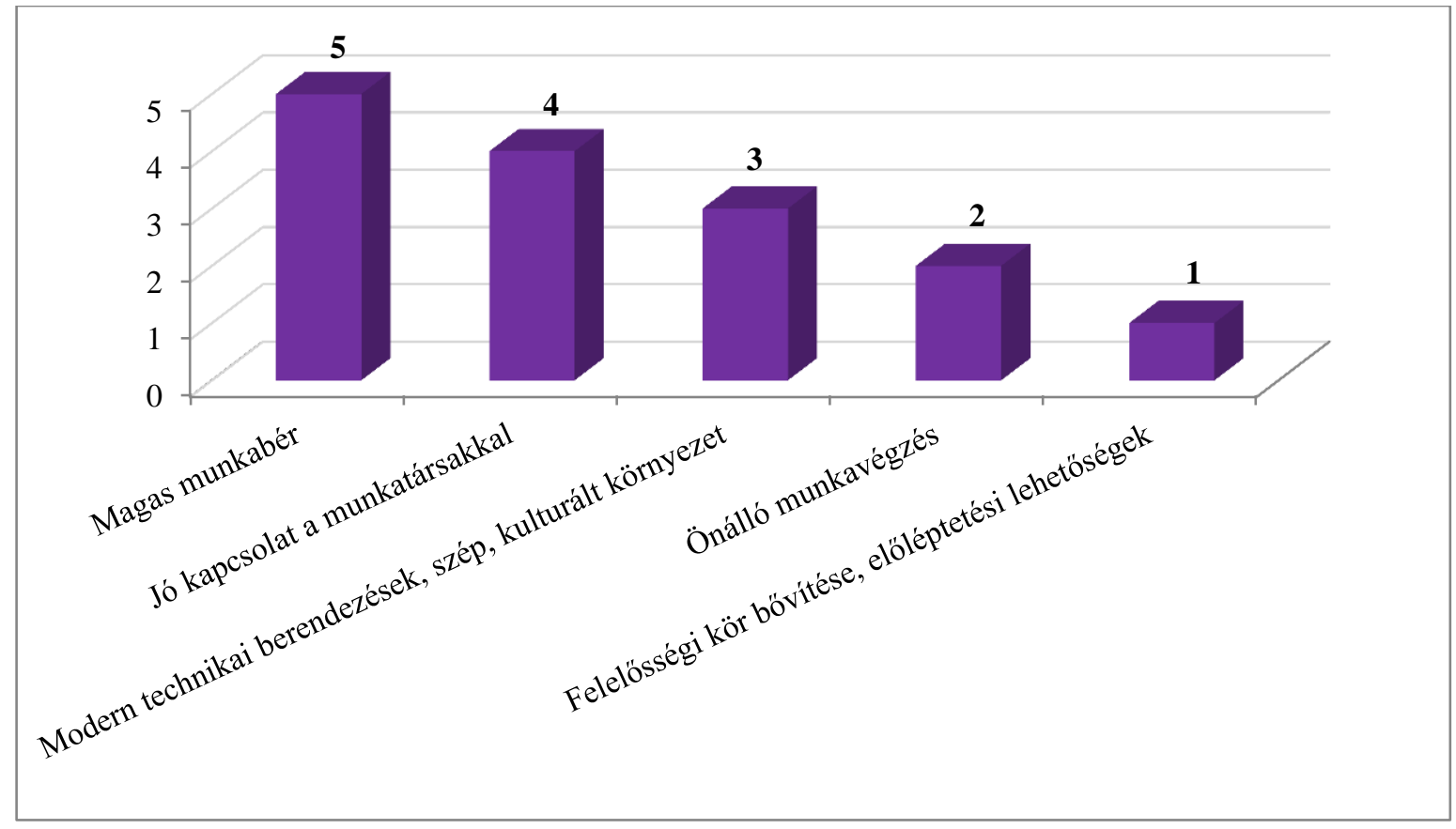

2. ábra: Motivációs eszközök értékelése az összes korosztály által

(Forrás: Saját adatbázis alapján)

A második kérdés során a felsorolt motivációs eszközöket kellett rangsorolni. A 2. ábrán az összes korosztály összesített véleménye látható. Ez alapján elmondható, hogy a Kft alkalmazottai körében a legmotiválóbb tényező a magas munkabér, amely az ábrán a maximális öt pontot kapta. Rögtön utána az emberek számára a jó munkahelyi viszony, a jó kapcsolatok kialakítása a fontos, amely négy pontot szerzett, majd három ponttal a modern technikai berendezések, szép kulturált környezet foglalhatja el a képzeletbeli dobogó harmadik fokát. A válaszadók számára az önálló munkavégzés kettő pontot ért, és a legkevésbé fontos motivációs eszköz az értékelésük alapján a felelősségi kör bővítése, az előléptetési lehetőség volt. A baby boom generáció számára motiváló tényezőként jelenik meg a magas 
munkabér, majd rögtön ezután a jó munkatársi kapcsolatok következnek. Számukra a harmadik helyen az önálló munkavégzés áll. Nem meglepő, hogy az értékelésük során a modern berendezések és a kulturált környezet csak a negyedik helyen szerepel. A felelősségi kör bővítését, az előléptetési lehetőségeket egyáltalán nem tartják fontosnak. Az X generáció is az első két helyre rangsorolta a magas munkabért és a jó munkahelyi kapcsolatokat. A harmadik helyre itt a modern technikai berendezések kerültek, és az önálló munkavégzés számukra kevésbé fontos. Az Y generáció számára a magas munkabér lett a legfontosabb a felsorolt eszközök között. A cégnél dolgozó legfiatalabb generáció szinte hallani sem akar a felelősségi kör bővítéséről és az előléptetési lehetőségről. Mindössze a válaszadók negyedének volt fontos ez a motivációs tényező. Egy y generáció körében végzett korábbi kutatás azt mutatja, hogy a munkavállalás előtt állva az anyagi ellenszolgáltatás, az önérvényesítés és a fizikai környezet a legfontosabb munkaérték számukra. És kevésbé jelentős a társas kapcsolatok és a kreativitás (Gergely et al., 2016).

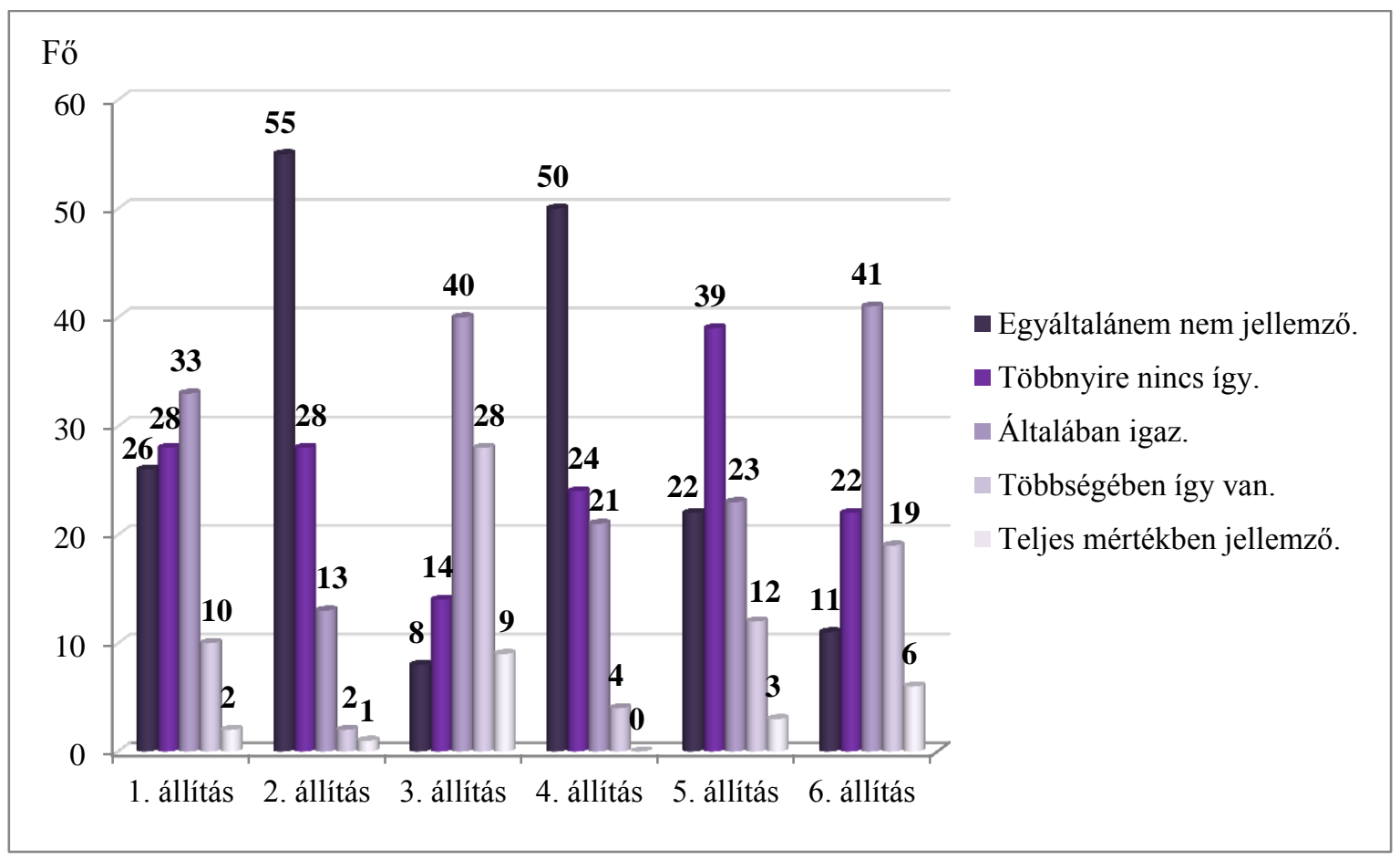

3. ábra: A beosztottak értékelése a jelenlegi munkahelyükkel kapcsolatban az összes korosztály által (Forrás: Saját adatbázis alapján)

A 3. ábra az összes beosztott véleményét mutatja a munkahelyükön uralkodó jelenlegi helyzet alapján. Ebben a kérdéssorban az első kérdésnél arra voltunk kíváncsiak, hogy a vezetők mennyire szokták érzékeltetni, a beosztottak tudomására hozni azt, hogy milyen jól végzik a munkájukat. 33 fő gondolta úgy, hogy ezt általában megteszik. A második kérdés a továbbképzésekre, csapatépítő tréningekre vonatkozott. Összesen 83 fő vélekedett úgy, hogy a cég nem igazán szokott ilyen rendezvényeket kezdeményezni. A harmadik kérdés a célkitűzésekkel, a tervek ütemezésével volt kapcsolatos. A beosztottak többsége az eredmény szerint tisztában van ezekkel. A kérdéssor negyedik kérdésében az érdekelt minket, hogy a vezetők mennyire kérik ki a beosztottak véleményét egy-egy fontosabb kérdés meghozatalakor. A válaszolók közel negyede azt állította, hogy a feletteseik érdeklődni szoktak a 
véleményük iránt. Az ötödik kérdésben arra voltunk kíváncsiak, hogy mennyire egyhangúak, monotonok az elvégzendő feladatok. A többség talál változatosságot a napi munkájában. A kérdéssor utolsó kérdésénél a többség vidám, közvetlen környezetként tudta jellemezni a munkahelyét. A baby boom generáció számára a magasabb munkabér és a növekvő béren kívüli juttatások jelentek meg motivátorként. Továbbá a válaszolók 75\%-át ösztönzi a vezetők általi pozitív visszajelzés, illetve a folyamatos képzési lehetőségek ösztönző hatással vannak a munkavállalókra. A beosztottak 58\%-a úgy vélte, hogy növeli a munka iránti motivációjukat, ha tisztában vannak az előlépési lehetőségekkel, míg 42\%-át egyáltalán nem érdekelte ez. A válaszadók 83\%-a szerint a munkahelyi biztonság, ha nem kell félnie az elbocsátástól pozitívan hat a munkájára. A jó munkahelyi kapcsolat pedig csak egyetlen embert nem motivált a baby-boom generációból. Az X generációt leginkább a jó munkahelyi kapcsolatok és a béren kívüli juttatások növelése ösztönzi, legkevésbé pedig az előrelépési lehetőség. Az Y generáció munka iránti motivációját meghatározza a magasabb munkabér, növekvő béren kívüli juttatások, nagyobb felelősséggel járó feladatokkal való megbízás, pozitív vezetői dicséret, folyamatos képzés, tisztázott előrelépési lehetőségek, biztos munkahely, valamint a jó munkahelyi kapcsolatok. A magas munkabér és a béren kívüli juttatások emelése nem meglepő módon a válaszadók több mint 90\%-át ösztönözné a produktívabb munkavégzésre. Az Y generációt is leginkább a biztos munkahely és a jó munkahelyi kapcsolatok motiválja, hasonlóan a baby boom generáció tagjaihoz.

Kérdőívünkben megvizsgáltuk a vállalat iránti lojalitást, a túlóra és a munkabér viszonylatában, ehhez kapcsolódóan a tűrőképességüket. A baby boom generáció arra a kérdésre, hogy mennyi idő alatt mondana fel a jelenlegi munkahelyén, ha napi több órát kellene túlóráznia alacsony munkabérért rossz munkahelyi kapcsolatok mellett azzal az eredménnyel szolgált, hogy nem tolerálnák ezt a szélsőséges esetet, és a korosztály tagjainak több mint fele azonnal felmondana. Ha nem kellene túlórázni, megfelelő bért kapna, de a munkahelyi kapcsolatai rosszak lennének, akkor a válaszadók azonnal felmondanának. Ha pedig nem kellene túlórázni, de a bérezés alacsony, a munkahelyi kapcsolatok viszont jók lennének, ebben az esetben is azonnal felmondanának a válaszadók. Az utolsó esetben a rossz faktor a napi több órás túlórázás volt, amit a korosztály többsége nem vélt komoly problémának, így megvárnák az adott időszak végét a vállalat életében, és nem mondanának fel. Az eredmények alapján elmondható, hogy a vállalatnál dolgozó baby boom generáció tagjainak igen alacsony a tűrőképessége. Az X generáció tagjait sem a rossz munkahelyi kapcsolatok, sem az alacsony bérezés nem tántorítaná el. A napi több órás túlóra még nem jelentene számukra felmondási okot. Az X-ek által adott válaszok összességében történő értékelésekor elmondhatjuk, hogy a társaság alkalmazottainak igen magas a tűrőképessége. Az Y generáció is az azonnali felmondást választaná akkor, ha sokat kellene túlórázni alacsony bérért rossz munkahelyi kapcsolatok mellett. Ha a munkahelyi kapcsolatokkal lennének problémák, akkor inkább kitartanának, és megvárnák, amíg rendeződik a helyzet. Amennyiben alacsony munkabérért kellene dolgozniuk, úgy fél éven belül elhagynák a céget az Y generáció munkavállalói. Az utolsó helyzetben a negatív paraméter a rengeteg túlórázás volt, ami láthatólag egyáltalán nem okozna gondot a számukra. Több mint 86\%-a a válaszadóknak kivárná a kritikus időszak végét, és nem mondana fel. 


\section{Következtetések, javaslatok}

A beosztottak egyetértettek abban, hogy a társaságnál vidám, közvetlen környezetben változatos feladatokat kell elvégezniük nap, mint nap. Továbbá azt is akceptálták, hogy a célkitűzéseket, a tervek ütemezését a felettesek minden esetben megosztották velük. A kapott eredmények alapján megfogalmaztuk a vállalat számára a fejlesztési lehetőségeket. A legfontosabb lépésként egy teljesítménymenedzsment rendszer kialakítását tartanánk fontosnak. A munkavállalókban lévő potenciál és kompetenciák felismerése, valamint azokra történő építés a vezető feladata egy szervezeten belül. A három generáció együttes véleménye alapján a kitöltők közel felét a folyamatos, fejlesztés és a tisztázott előrelépési lehetőségek motiválják, ezért következő lépésként célszerű a munkaerő-fejlesztés és a munkakör-gazdagítás, valamint a karriermenedzsment kialakításának témáját napirendi pontnak felvenni, így ösztönözve az Y generáció lojalitásának és elkötelezettségének növekedését a cég irányába. A következő cél ezt követően egy kompetencia-térkép és a kompetenciamenedzsment kialakítása lehetne, abból kifolyólag, hogy adott időközönként javasolt a vállalat munkatársainak képességeit felmérni mind vezetői, mind beosztott szemszögből is. Ez a vizsgálat feltárja, hogy a cég alkalmazottai a saját képességeinek, tudásának és motivációjának megfelelő pozícióban dolgoznak-e. Amennyiben a válasz nemleges, akkor vagy a számára testhezálló munkakörbe kell áthelyezni, vagy ki kell deríteni, hogy milyen mértékben képes és hajlandó fejlődésre az adott személy. Ha a munkavállaló elutasító viselkedést mutat az elemzés során, akkor érdemes elgondolkozni az egyéntől való megválásról. Ez a térkép a továbbiakban az új munkatárs kiválasztásában is fontos szerepet kaphat. Kardinális irányvonal lehetne az önfejlesztés bátorítása mind a beosztottak, mind pedig a vezetők számára, amely esetében egyéni és szervezeti kezdeményezés is elképzelhető. A csoportos tréningek, továbbképzések is jó választás lehet a társak húzó és motiváló ereje miatt. Ezeket a kezdeményezéseket akár a vállalat a következő éves céljai közé is beveheti. Fontos, hogy a vállalat munkatársai egymásra egy nagy közösség egyenrangú tagjaiként tekintsen. Ennek érdekében az összetartozás érzését kell erősíteni bennük, aminek a legegyszerübb és leghatékonyabb módja az évente több csapatépítő tréning szervezése.

\section{Összegzés}

Tanulmányunk célja az volt, hogy a vállalaton belül megvizsgáljuk a szervezeti magatartást, illetve a motivátorokat, és javaslatot tegyünk a fejlődési lehetőségekkel kapcsolatban. A szervezet elemzéséhez először a szervezetben dolgozókat soroltuk be a generációs elméleteket alapul véve. A csoportok kialakítása után megállapítottuk, hogy a baby boom generáció számára motiváló tényezőként jelenik meg a magas munkabér, a növekvő béren kívüli juttatások, a jó munkatársi kapcsolatok, illetve az önálló munkavégzés. A modern berendezések és a kulturált környezet nem hat rájuk motiválóan. A felelősségi kör bővítését, az előléptetési lehetőségeket egyáltalán nem tartják fontosnak. A baby boomerekre a vezetők általi pozitív visszajelzés, valamint a folyamatos képzési lehetôségek ösztönző hatással vannak. Növeli a munka iránti motivációjukat, ha tisztában vannak az előlépési lehetőségekkel. A munkahelyi biztonság, ha nem kell félnie az elbocsátástól pozitívan hat a munkájára. A vállalatnál dolgozó baby boom generáció tagjainak igen alacsony a tűrőképessége. Az X generációnak 
is a magas munkabér és a jó munkahelyi kapcsolatok a legfőbb motiváló tényezők, illetve a modern technikai berendezések. Azonban az önálló munkavégzés, az előrelépési lehetőségek számukra kevésbé fontos hasonlóan a vezetői dicséretekhez és a folyamatos képzési lehetőségekhez. Ugyanakkor a kor szülöttei számára felettébb lényeges a munkahelyi biztonság. A kutatásunk alapján az is elmondható, hogy a vállalat alkalmazottai közül az X-ek tűrőképessége a legmagasabb. Az Y generációt leginkább a jó munkahelyi kapcsolatok, a magas munkabér, valamint a béren kívüli juttatások növelése ösztönzi. A cégnél dolgozó legfiatalabb generáció szinte hallani sem akar a felelősségi kör bővítéséről és az előléptetési lehetőségről. Számukra is meghatározó a biztos munkahely. Ők azok a munkavállalók, akiket nemcsak motivál, de igénylik is a pozitív vezetői visszajelzést. A szituációs játékunk alapján elmondható, hogy az Y generációnak is igen magas a tűrőképessége, hiszen kivárná a vállalat életében bekövetkező esetleges kritikus időszak végét, és nem mondana fel.

\section{Felhasznált irodalom}

[1] V. Anantatmula - B. Shrivastav (2012) Evolution of project teams for Generation Y workforce. International Journal of Managing Projects in Business, 5 (1) pp.9-26.

[2] J. W. Atkinson (1964) An Introduction to Motivation. D. van Nostrand Company Inc.

[3] A. Ferincz - Zs. Szabó (2012) Z generáció hatása a munkáltató szervezetekre. Munkaügyi Szemle, 56 (2) pp. 88-89

[4] K. A. Kópházi (2007) A motiváció szerepe a munkavállalói lojalitás megteremtésében. Humánpolitikai szemle, 18 (4) pp. 51-56.

[5] B. Klein - S. Klein (2012) A szervezet lelke. EDGE 2000 Kiadó, Budapest. ISBN: 978-963-976022-6

[6] D. H. Pink (2010) Motiváció 3.0 - Ösztönzés másképp. HVG Kiadó Zrt., Budapest. ISBN: 9789633040201

[7] B. Schaffer (2012) Különböző értékek: A „baby boom” generáció. http://www.hrblog.hu/ifjutitanok/2012/07/02/kulonbozo-ertekek-baby-boomgeneracio/, Letöltés ideje: 2017.12.05., 9:18

[8] S. Takács - S. Csillag - Cs. Kiss - R. Szilas (2012) Még egyszer a motivációról, avagy „Hogyan ösztönözzük alkalmazottainkat itt és most?” Vezetéstudomány, 43 (2) pp. 2-17.

[9] A. Tari (2010) Y generáció - Klinikai pszichológia jelenségek és társadalomlélektani összefüggések az információs korban. Jaffa Kiadó, Budapest. ISBN: 9789639971202

[10] G. Tóthné Sikora (2004) Humán erőforrások gazdaságtana. Bíbor Kiadó, Miskolc.

[11] P. Trunk (2009) What generation $Z$ will be like at work. http://blog.penelopetrunk.com/2009/07/27/what-work-will-be-like-for-generation-z/, Letöltés ideje: 2017.12.08. 10:25

[12] G. Árváné Ványi Katonáné - J. Kovács - T. Gál (2017) A vállalkozásfejlesztés oktatásának vizsgálata a magyar felsőoktatásban. Vezetéstudomány, 48 (6-7) pp. 49-56.

[13] G. Árváné Ványi - J. Katonáné Kovács - T. Gál - P. Popovics (2016) Vállalkozói képzés a 21. században a felsőoktatásban - lehetôségek, módszerek, jó gyakorlatok. International Journal of Engineering and Management Sciences (IJEMS), 1 (1) DOI: 10.21791/IJEMS.2016.1.1. 
[14] T. Gál - P. Popovics - J. Katonáné Kovács - G. Árváné Ványi (2017) Szervezeti kultúra és vezetői tulajdonságok vizsgálata az észak-alföldi régióban. TAYLOR Gazdálkodás- és szervezéstudományi folyóirat A Virtuális Intézet Közép-Európa Kutatására Közleményei, 9 (2) pp. 14-22.

[15] É. Gergely - I. Zs. Hágen - A. Pierog (2016) Munkaérték és karrierhorgony - egyetemisták körében végzett felmérés eredményei. Acta Carolus Robertus : Károly Róbert Főiskola Gazdaságés Társadalomtudományi Kar Tudományos Közleményei, 6 (2) pp. 162-178. 